\title{
INSEGURANÇA JURÍDICA NA JURISDIÇÃO CONSTITUCIONAL DO SUPREMO TRIBUNAL FEDERAL: PROTAGONISMO DO PODER JUDICIÁRIO NO ESTADO DEMOCRÁTICO DE DIREITO, JUDICIALIZAÇÃO DA POLÍTICA, ATIVISMO E AUTORRESTRIÇÃO JUDICIAL
}

\author{
PARLIAMENTARIATE NATURE OF \\ PROVISIONAL MEASURES: IMBALANCE \\ OF FORCES BETWEEN EXECUTIVE \\ AND LEGISLATIVE POWERS IN THE \\ PRESIDENTIALIST GOVERNMENT SYSTEM
}

\section{Marco Vicente Dotto Köhler ${ }^{1}$}

Resumo: $\mathrm{O}$ trabalho analisa se há a possibilidade de ocorrer insegurança jurídica como consequência de julgamentos de casos concretos com fatos e fundamentos jurídicos similares entre si, mas para os quais o Supremo Tribunal Federal, em sua função jurisdicional, proferiu decisões divergentes. Ao dar respostas distintas a situações similares, o Supremo dificulta a previsibilidade das decisões e gera insegurança jurídica, repercutindo de forma danosa ao Estado Democrático de Direito. Para melhor compreensão deste trabalho, é necessário estudar do constitucionalismo, da evolução dos direitos fundamentais, do crescimento do protagonismo do Poder Judiciário e do papel do Supremo Tribunal Federal de interpretar a Constituição, com o dever de respeitar o texto constitucional, sendo que para modificar seu posicionamento decisório, deve arcar om o ônus hermenêutico que isso enseja.

Palavras-chave: Insegurança jurídica.

1 Técnico judiciário auxiliar, lotado a comarca de Lauro Müller-SC, onde ocupa os cargos de Distribuidor Judicial e Assessor de Gabinete. Pós-graduado, em nível de Especialização, pela Universidade Anhanguera-Uniderp, por meio da rede LFG, em Direito Constitucional. Egresso da Escola Superior da Magistratura do Estado de Santa Catarina (Esmesc). E-mail: dottokohler@yahoo.com.br 
Supremo Tribunal Federal. Estado democrático de direito.

Abstract: This article analyzes whether there is a possibility of legal uncertainty as a consequence of judgments of real cases with similar facts and legal bases, but for which the Supreme Court of Brazil, in its jurisdictional function, rendered opposing decisions. By giving different answers to similar situations, the Supreme Court hinders the predictability of decisions and creates legal uncertainty, dama- ging the Democratic State of Law. To better understand this work, it is necessary to study constitutionalism, the evolution of fundamental rights, the growing role of the Judiciary and the role of the Federal Supreme Court to interpret the Constitution, with the duty to respect the constitutional text, and to modify its decision-making position, must be the hermeneutical burden that this entails.

Keywords: Legal Uncertainty. Federal Supreme Court. Democratic State of Law.

\section{INTRODUÇÃ̃O}

O presente trabalho científico foi elaborado inicialmente em forma de monografia, como trabalho de conclusão de curso da pós-graduação lato sensu em Direito Público da Escola da Magistratura do Estado de Santa Catarina (Esmesc).

Para possibilitar o compartilhamento do resultado do estudo, foi feito o presente artigo jurídico, cujo objeto é o estudo comparado de decisões juridicamente divergentes em situações fáticas e jurídicas similares, proferidas por Ministros do Supremo Tribunal Federal.

Pretende-se perquirir se houve caráter ativista ou autorrestritivo nas decisões, e a possibilidade de que haja insegurança jurídica em decorrência de respostas jurídicas divergentes a casos semelhantes, bem como será demonstrada a importância de se manter a segurança jurídica, por ser fator de estabilidade para o Estado Democrático de Direito e para a Democracia.

Para melhor compreensão, o desenvolvimento será dividido em quatro partes principais, nas quais serão tratados os assuntos essenciais ao trabalho.

A primeira parte sobre constitucionalismo e protagonismo 
do Poder Judiciário sobre os demais Poderes da República, mormente no período posterior à II Guerra Mundial.

A segunda demonstra os contornos do ativismo e da autorrestrição judiciais, relacionando-os com a separação dos poderes, e diferenciação entre judicialização da política e a politização da Justiça.

$\mathrm{Na}$ terceira é realizado o estudo comparativo das decisões antagônicas do Supremo Tribunal Federal proferidas nas medidas cautelares em Mandado de Segurança n. 34.070 (caso Lula) e n. 34.609 (caso Moreira Franco), bem como entre as decisões das Ações Cautelares n. 4.039 (caso Delcídio) e n. 4.327 (caso Aécio).

Por fim, é feita a análise quanto a ter havido ou não caráter ativista ou autorrestritivo na atuação do Supremo Tribunal Federal ao decidir tais questões, bem como se as decisões diferentes para casos similares contribuem para a insegurança jurídica no Estado Democrático de Direito.

\section{CONSTITUCIONALISMO}

Para abordar o constitucionalismo, em especial o constitucionalismo no período posterior à II Guerra Mundial, que tem na Constituição a representação máxima dos valores do povo que a proclama, e poder demonstrar o protagonismo do Judiciário no Estado Democrático de Direito, é preciso tratar, mesmo que brevemente, da evolução e das gerações dos direitos fundamentais.

\subsection{Estado Democrático de Direito e a evolução dos direitos fundamentais}

Tamanha é a importância do Estado Democrático de Direito, que a Constituição Federal, em seu Art. $1^{\circ}$, caput, eleva tal 
conceito, colocando-o como um dos Princípios Fundamentais da República Federativa, que "[...] constitui-se em Estado Democrático de Direito [...]" (BRASIL, 1988).

O Estado Democrático de Direito não é apenas a junção dos conceitos de Estado Democrático e de Estado de Direito, mas um conceito novo, sobre o qual a Constituição proclama e funda o Estado, e que tem como princípios (i) a constitucionalidade; (ii) o princípio democrático; (iii) o sistema de direitos fundamentais; (iv) o princípio da justiça social; (v) o princípio da igualdade; (vi) o princípio da divisão de poderes e independência do juiz; (vii) o princípio da legalidade e (viii) o princípio da segurança jurídica (SILVA, 2008, p.119-122).

Os direitos fundamentais têm suas origens no Século XVIII e podem ver no lema que norteou a Revolução Francesa, expressados "[...] em três princípios cardeais, todo o conteúdo possível dos direitos fundamentais, [e] até mesmo a sequência histórica de sua gradativa institucionalização: liberdade, igualdade e fraternidade" (BONAVIDES, 2006, p.562).

No que tange especificamente à evolução dos direitos fundamentais, primeiramente cabe "alertar que a doutrina, por vezes, utiliza as expressões dimensões ou gerações para exprimir a evolução dos direitos fundamentais" (FILETI, 2009, p. 44).

Para os defensores do termo "dimensão", este seria a evolução da palavra geração, pois "[...] um direito só pode ter várias dimensões, a exemplo do direito de propriedade, que passou do campo privado para o constitucional e, por derradeiro, para o ambiental [...]", e, sendo assim, o termo "dimensão" retrataria, "[...] com maior nitidez, o caleidoscópio das liberdades públicas" (BULOS, 2018, p. 529).

Para Sarlet (2015, p.45), o termo "geração" não deveria ser utilizado para designar a evolução dos direitos fundamentais, sendo que o termo "dimensão" seria mais apropriado, 
pois a palavra geração “[...] além da imprecisão terminológica já consagrada, conduz ao entendimento equivocado de que os direitos fundamentais se substituem ao longo do tempo, não se encontrando em permanente processo de expansão, cumulação e fortalecimento".

No entanto, os direitos de gerações anteriores são "infraestruturais" aos direitos das gerações seguintes, não sendo utilizado o termo "geração" no sentido de substituição de uma geração por outra, mas de soma, pois "os direitos de quarta geração não somente culminam a objetividade dos direitos das duas gerações antecedentes como absorvem - sem, todavia, removê-la - asubjetividade dos direitos individuais, a saber, os direitos de primeira geração" (BONAVIDES, 2006, p. 572, grifos no original).

O termo "geração", por sua vez, por vários motivos é tido como o mais apropriado, "[...] porque demarca muito bem os períodos de evolução das liberdades públicas [e] seu uso, ao contrário do que se pode imaginar, demonstra a ideia de conexão de uma geração à outra" e isso se dá porque "[...] a geração mais nova não elimina as anteriores" (BULOS, 2018, p. 529, grifos no original).

Assim, no presente trabalho, para tratar da evolução dos direitos fundamentais, será utilizado o termo geração, que "[...] demarca muito bem os períodos de evolução das liberdades públicas [e] seu uso, ao contrário do que se pode imaginar, demonstra a ideia de conexão de uma geração à outra" e isso se dá porque "[...] a geração mais nova não elimina as anteriores" (BULOS, 2018, p. 529, grifos no original).

Os da primeira geração “[...] são os direitos da liberdade, os primeiros a constarem do instrumento normativo constitucional, a saber, os direitos civis e políticos, que em grande parte correspondem [...] àquela fase inaugural do constitucionalismo 
do Ocidente" (BONAVIDES, 2006, p. 563).

Os da segunda geração "são os direitos sociais, culturais e econômicos bem como os direitos coletivos ou de coletividades, introduzidos no constitucionalismo das distintas formas de Estado social, depois que germinaram por obra da ideologia e da reflexão antiliberal do século XX” (BONAVIDES, 2006, p. 564).

Os da terceira geração, por seu turno, são "dotados de altíssimo teor de humanismo e universalidade, [...] tendem a cristalizar-se no fim do século XX enquanto direitos que não se destinam especificamente à proteção dos interesses de um indivíduo, de um grupo ou de um determinado Estado" sendo que os destinatários a humanidade, o gênero humano, e são "[...] o coroamento de uma evolução de trezentos anos da esteira da concretização dos direitos fundamentais." (BONAVIDES, 2006, p. 569).

Indo além do tripé de princípios da Revolução Francesa, já no final do século XX, impulsionados pela globalização política e econômica, há também a tendência à globalização dos direitos fundamentais, universalizando-os no campo institucionalização do Estado Social (BONAVIDES, 2006, p. 571), culminando na quarta geração de direitos fundamentais, que abarca "[...] o direito à democracia, o direito à informação e o direito ao pluralismo [e] deles depende a concretização da sociedade aberta ao futuro [...]" (BONAVIDES, 2006, p. 571).

A quinta geração de direitos fundamentais seria o "direito à paz", como fundamento e objetivo de se ter "direito à vida pacífica como um direito de fraternidade" (BULOS, 2018, p.530-531).

Por fim, a sexta geração de direitos fundamentais corresponde ao direito "[...] à democracia, à liberdade de informação, ao direito de informação e ao pluralismo" (BULOS, 2018, p. 531). 


\subsection{Constitucionalismo no período posterior à II Guerra Mundial}

A constituição é pilar do Estado como instituição permanente, que vai além "das circunstâncias e dos detentores em concreto do poder [pois revela] a prevalência dos elementos objetivos ou objetivados das relações políticas; é esteio, senão da legitimidade, pelo menos da legalidade" (MIRANDA, 2015, p. 165).

Para José Afonso da Silva (2008, p. 39-40),

A constituição é algo que tem, como forma, um complexo de normas (escritas ou costumeiras); como conteúdo, a conduta humana motivada pelas relações sociais (econômicas, políticas, religiosas etc); como fim, a realização dos valores que apontam para o existir da comunidade; e, finalmente, como causa criadora e recriadora, o poder que emana do povo. Não pode ser compreendida e interpretada, se não se tiver em mente essa estrutura, considerada como conexão de sentido, como é tudo aquilo que integra um conjunto de valores (grifos no original).

Dessa forma, "em qualquer Estado, em qualquer época e lugar, encontra-se sempre um conjunto de normas fundamentais, respeitantes à sua estrutura, à sua organização e à sua atividade", o que permite concluir, sem oposição, que "encontra-se sempre uma Constituição como expressão jurídica do enlace entre poder e comunidade política ou entre governantes e governados" (MIRANDA, 2015, p. 165).

No presente trabalho, quando se trata de constitucionalismo, é no sentido mais abrangente, pois "se adotado um conceito amplo de constitucionalismo, não haveria que falar em neoconstitucionalismo, pois ele seria somente mais um dos vários momentos de reflexão sobre a experiência político-jurídica de uma sociedade e de um Estado", e, nesse sentido, seria, portanto, o constitucionalismo contemporâneo denominado 
não de neoconstitucionalismo, mas de "constitucionalismo na segunda metade da era da modernidade" (FRANCISCO apud FONTES, 2018, p. 85-86).

Há pouco mais de dois séculos se incorporou o termo constitucionalismo ao vocabulário político e jurídico no ocidente, relacionando-se tanto com a revolução francesa quanto com a americana e significa, essencialmente, "limitação do poder e supremacia da lei [...] e mesmo que sugira explicitamente a existência de uma constituição escrita, existem ideais constitucionalistas independentemente de constituição escrita, como no caso do Reino Unido" (BARROSO, 2016, p. 28-29).

Pode-se caracterizar as limitações em três frentes, em especial: (i) as de ordem material, que se caracterizam e se balizam pela dignidade da pessoa humana; (ii) vinculadas a uma estrutura orgânica, que se relaciona à existência, separação, equilíbrio e harmonia dos poderes (checkand balances); e as (iii) processuais, que guarnecem não apenas a legalidade, mas o devido processo legal no manejo das leis (BARROSO, 2016, p. 29-30).

\subsection{Protagonismo do Poder Judiciário no Estado Democrático de Direito}

A Constituição do Brasil, de 1988, conforme classificação doutrinária quanto à sua extensão, é analítica, ampla, detalhista, minuciosa e pleonástica (BULOS, 2018), e por isso “[...] produz importantes impactos na realidade política brasileira, interferindo no funcionamento concreto das instituições nacionais" (SARMENTO, 2017, p. 60)

Como será visto, não é apenas da extensão do texto constitucional que decorre o protagonismo do Judiciário. Isso se dá não apenas no Brasil, mas faz parte de uma "evolução da jurisdição constitucional [...] principalmente a partir do período pós-segunda guerra.” (ALVES; LEAL, 2015, p. 77). 
No Brasil, esse fenômeno vem em uma crescente, principalmente no período posterior à Constituição de 1988, que marcou a redemocratização, sendo que "[...] houve uma transferência, ocasionada por um processo complexo, provocado por diferentes fatores, das questões políticas mais emblemáticas, ao Poder Judiciário, o que leva à afirmação de que há certo protagonismo deste em relação aos demais Poderes" (ALVES; LEAL, 2015, p. 77).

\section{ATIVISMO JUDICIAL}

Para tratar de ativismo judicial é preciso dar ênfase para a função do Poder Judiciário e, para isso, é preciso discorrer sobre a separação de poderes.

\subsection{Separação de Poderes e atuação do Poder Judiciário em sua função judicante}

No Brasil atual, a Constituição da República, de 1988, em seu art. $2^{\circ}$, traz a separação dos Poderes da União, ao determinar que Legislativo, Executivo e Judiciário são independentes e harmônicos entre si (BRASIL, 1988) e tem especial atenção do Constituinte, que elencou a Separação dos Poderes dentre as cláusulas pétreas (Art. 60, $\S 4^{\circ}$, III, da Constituição Federal), limitando materialmente o poder de reforma. (BULOS, 2018, p. 412).

As funções legislativa, administrativa e jurisdicional são atribuídas a órgãos distintos, independentes entre si, que devem manter o equilíbrio de forças, pois para se manter os freios e contrapesos, "[...] o poder deve conter o poder [...]" ainda que "[...] o delicado equacionamento de forças entre Poderes, no Brasil, não poderá seguir, à risca, a proposta dos autores clássicos, notadamente Montesquieu", pois no atual momento histórico e de evolução das instituições democráticas, "[...] 
cada uma dessas funções não é, em absoluto, estanque uma da outra" (BULOS, 2018, p. 1089, grifos no original).

Importante dizer que a simples atuação do Judiciário, ainda que interprete criativamente o texto da Constituição, "[...] não pode, por si só, receber a alcunha pejorativa de 'ativista' [pois] a atividade do exegeta é naturalmente criativa, não sendo incompatível com os limites institucionais constitucionalmente impostos ao Judiciário." (PASSOS, 2014, p. 143).

A utilização das cortes constitucionais pode ser uma forma de "[...] fortalecimento da democracia representativa [...]" sendo que "[...] o crescente papel institucional das cortes constitucionais pode ser concebido não como ameaça à representação, às instituições representativas ou à democracia [..]" e sim deve ser tido "[...] como um sinal de que a primeira precisa ser ressignificada, as segundas reconfiguradas e a terceira fortalecida" (POGREBINSCHI, 2011, p. 165).

\subsection{O Ativismo Judicial e a Autorrestrição Judicial}

O termo "ativismo judicial" foi utilizado publicamente pela primeira vez no ano de 1947 por Arthut Schlesinger Jr, "[...] e o fez em oposição à 'autorrestrição judicial"”. (CAMPOS, 2017, p. 245).

A autorrestrição judicial, por sua vez, ainda que seja um contraponto do ativismo judicial, tem a mesma origem, que é a "[...] atuação expansiva das cortes constitucionais e supremas em diferentes cantos do mundo." (CAMPOS, 2017, p. 242).

Para Schlesinger, na análise de Campos (2017, p. 245), o ativismo ocorre por meio da atuação de juízes que "[...] substituem a vontade do legislador pela própria [...]" com a intenção de proporcionar liberdades civis, direitos de grupos minoritários e de pessoas desprovidas de proteção do Estado, podendo até efetuar uma espécie de correção judicial do que entendem 
ser um erro do legislador. Na outra ponta, os juízes que atuam com maior ênfase na autorrestrição entendem que não devem intervir na política, agindo com deferência ao legislador.

O que pode ser extraído da atuação do judiciário em relação à deferência ou não ao legislador, é que "o verdadeiro perigo a prevenir não está, portanto, em que os juízes sejam criadores do direito e como tais se apresentem, mas que seja pervertida a característica formal essencial, isto é, o 'modo' do processo jurisdicional”'(CAPPELLETTI, 1999, p. 132).

Colocando-se frente a frente ativismo e autorrestrição, " [...] se ativismo judicial é enfrentar os outros poderes, autorrestrição é evitar decidir contra esses poderes [...]" e, talvez mais importante para o equilíbrio entre os poderes, e preservação do princípio da separação de poderes, a autorrestrição judicial busca em relação aos demais poderes "[...] dar-lhes o benefício da dúvida sobre a legitimidade e correção material de seus atos, ainda que os juízes sejam pessoalmente contrários a essas decisões." (CAMPOS, 2017, p. 251).

\section{ESTUDOS DE CASOS: MEDIDAS CAUTELARES EM MANDADOS DE SEGURANÇA N. 34.609 E N. 34.070; E AÇÕES CAUTELARES N. 4039 E N. 4.327, DO SUPREMO TRIBUNAL FEDERAL}

Por fim, chega-se ao ponto principal do presente trabalho, em que serão analisadas algumas decisões recentes do Supremo Tribunal Federal, nas quais a Corte decidiu de forma diversa, em curto espaço de tempo, situações fáticas e jurídicas similares.

\subsection{Mandado de Segurança n. 34.070 (Caso Lula)}

O Mandado de Segurança n. 34.070 foi impetrado pelo Partido Popular Socialista - PPS perante o Supremo Tribunal Federal em 17/03/2016, objetivando impedir que fosse efetivada 
a nomeação, pela então Presidente da República, Dilma Rousseff, de Luiz Inácio Lula da Silva para o cargo de Ministro Chefe da Casa Civil.

No dia 18/03/2016 foi deferida liminar pelo Relator, Ministro Gilmar Mendes, para "[...] suspender a eficácia da nomeação de Luiz Inácio Lula da Silva para o cargo de Ministro Chefe da Casa Civil, determinando a manutenção da competência da justiça em Primeira Instância dos procedimentos criminais em seu desfavor." (STF, 2016, online).

Reconheceu o Ministro Relator como sendo "[...] muito claro o tumulto causado ao progresso das investigações, pela mudança de foro. E 'autoevidente' que o deslocamento da competência é forma de obstrução ao progresso das medidas judiciais" bem como reconheceu o fato, por si, que essa mudança de foro causaria "atraso e desassossego" ao andamento do procedimento, o que "poderia ser fatal para a colheita de provas, além de adiar medidas cautelares", sendo que "seria possível concluir que a posse em cargo público, nas narradas circunstâncias, poderia configurar fraude à Constituição." (STF, 2016, online).

Dessa forma, restou clara a decisão no sentido de atribuir a fraude à Constituição pela simples nomeação: "a simples nomeação, assim como a renúncia, demonstram suficientemente a fraude à Constituição." (STF, 2016, online).

O Relator expõe, como razão de decidir, de forma subjetiva, o que entendeu ser a intenção da Presidente da República intenção alheia, interpretação subjetiva de subjetivismo alheio, portanto - que teria nomeado Lula como Ministro pela "[...] crença de que o foro no STF seria leniente com o ex-Presidente" (STF, 2016, online), atribuindo à Presidente o objetivo de impedir a prisão. 


\subsection{Mandado de Segurança n. 34.609 (Caso Moreira Franco)}

O Mandado de Segurança n. 34.609 foi impetrado perante o Supremo Tribunal Federal no dia 07/02/2017 pelo partido político Rede Sustentabilidade, contra decreto do então Presidente da República, Michel Temer, que investiu Wellington Moreira Franco no cargo de Ministro de Estado Chefe da Secretaria-Geral da Presidência da República.

Sustentou o impetrante que a nomeação seria inválida, feita com desvio de finalidade, pois teria ocorrido com a finalidade de proporcionar ao nomeado "outorga de prerrogativa de foro", com o objetivo de "evitar o regular andamento das investigações em sede da operação Lava Jato" e com isso "impedir sua prisão e os regulares desdobramentos perante o juízo monocrático, [colocando] em risco a celeridade do julgamento".(STF, 2017, online).

Ao decidir, o Relator, Ministro Celso de Mello, resume a ação em forma de pergunta, que responde ao decidir:

A controvérsia suscitada na presente causa mandamental cinge-se a uma questão específica que pode ser resumida na seguinte indagação: a nomeação de alguém para o cargo de Ministro de Estado, mesmo preenchidos os requisitos previstos no art. 87 da Constituição da República, configuraria hipótese de desvio de finalidade pelo fato de importar - segundo sustenta o impetrante - em obstrução aos atos de investigação criminal supostamente provocada em razão de o Ministro de Estado dispor de prerrogativa de foro perante o Supremo Tribunal Federal? (STF, 2017, grifos no original).

Apesar de corroborar que é inquestionável que o desvio de finalidade é vício apto a ensejar a invalidade jurídica de ato administrativo, o pedido de liminar foi negado, pois o entendimento foi que, para existência de grave vício jurídico, deve 
estar configurada a

[...] intenção deliberada, por parte do administrador público, de atingir objetivo vedado pela ordem jurídica ou divorciado do interesse público [...] desígnio esse que não se presume, sob pena de subversão dos postulados referentes à presunção de legalidade, de veracidade e de legitimidade de que se reveste todo e qualquer ato emanado da Administração Pública. (STF, 2017,grifos no original).

Por fim, conclui o Relator que: (i) se preenchidos os requisitos constitucionais, a nomeação para cargo de Ministro de Estado, que terá foro por prerrogativa de função, não é, por esse fundamento em si, caracterizador de desvio de finalidade, pois não pode ser presumido tal desvio; (ii) o fato de Ministro de Estado ter prerrogativa de foro perante o Supremo Tribunal Federal não é privilégio de ordem pessoal, e sim prerrogativa decorrente da função; e (iii) é inconcebível que se permita atrelar o foro por prerrogativa de função perante o Supremo Tribunal Federal como sinônimo de impunidade, pois isso seria depreciar a dignidade do STF, mitigando, inclusive, a separação e autonomia dos Poderes da República.

\subsection{Análise comparativa entre as decisões das medidas cautelares em Mandados de Segurança $n$. 34.070 e n. 34.609}

Feitos os resumos fáticos e jurídicos das decisões analisadas, passa-se a analisar de forma comparativa a resposta jurisdicional oposta dada a ambas, ainda que similares entre si os fatos ensejadores das ações judiciais.

Há similaridade entre as situações fáticas analisadas, senão vejamos: (i) ambas tratavam de pessoas investigadas, (ii) que estavam na iminência de serem presas preventivamente, e que (iii) foram nomeadas para cargo de Ministro de Estado, com foro por prerrogativa de função; (iv) para, supostamen- 
te, impedir o curso das investigações e/ou colocar em risco o curso das investigações e (v) também evitar ou dificultar a prisão dos nomeados.

No Mandado de Segurança n. 34.070, o dolo, a intenção de fraudar a Constituição, foi tratado como subsidiário, pois seria apena pertinente à averiguação da prática de crime, de sendo a intenção do agente de desviar a finalidade do ato sido considerado fator secundário, sendo irrelevante sua comprovação para concessão da medida de segurança pretendida.

No Mandado de Segurança n. 34.609, tal quesito foi posto no centro da ação, pois deveria ser comprovada a intenção de agir com desvio de finalidade, com consequente fraude à Constituição, pois esse desvio não poderia ser presumido, sendo fundamental sua comprovação para a concessão da medida de segurança pretendida.

Apesar de estarem fundamentadas ambas as ações em situações similares, tanto fáticas quanto juridicamente, a resposta jurisdicional dada foi oposta.

Isso é perceptível ao verificar-se que no Mandado de Segurança n. 34.070 houve deferimento de liminar, a despeito das informações prestadas e da razoabilidade das explicações dadas por Presidente da República, tendo o Ministro Relator rechaçado as razões da defesa, interpretando a intenção do agente público, e atribuindo intenção subjetiva, ainda que negada em defesa.

Já no Mandado de Segurança n. 34.609, foram acolhidas as razões da defesa, não se imiscuindo o Ministro Relator na subjetividade da nomeação, pois a subjetividade seria inerente ao cargo de Presidente da República, que teria agido, portanto, dentro de suas atribuições.

Quanto à liminar, que foi negada neste caso, o Ministro 
Relator sustentou que não poderia ser deferida liminar em tal situação, pois seria reconhecer a impunidade de pessoas com foro por prerrogativa de função, bem como uma afronta à dignidade do Supremo Tribunal Federal, além de reconhecer a impossibilidade de punição antes do trânsito em julgado, em deferência ao princípio da presunção de inocência, previsto no art. $5^{\circ}$, LVII da Constituição Federal.

$\mathrm{Na}$ decisão que impediu a posse de Luiz Inácio Lula da Silva no cargo de Ministro de Estado (Mandado de Segurança n. 34.070), além de o Ministro Relator adentrar na subjetividade, atribuindo a própria interpretação da intenção de Presidente da República em nomear Ministro, ao julgar que a nomeação para tal cargo, com a consequente prerrogativa de foro pela função ascendendo ao Supremo Tribunal Federal, seria equivalente a salvo conduto capaz de possibilitar a impunidade e a prisão da pessoa nomeada.

Em ambos os casos a nomeação decorreu de ato de Presidente da República, de nomear como Ministro de Estado pessoa investigada e que, à época, era de conhecimento público a possibilidade de prisão dos respectivos nomeados.

No entanto, no caso da nomeação do Ministro Wellington Moreira Franco (Mandado de Segurança n. 34.609), o STF entendeu que seria afronta à dignidade da Suprema Corte pressupor impunidade pelo fato de o foro por prerrogativa de função deslocar-se para o Supremo Tribunal Federal, bem como não se adentrou ao mérito do ato, reconhecendo-se que o Presidente da República teria agido dentro de suas atribuições.

No caso da nomeação de Luís Inácio Lula da Silva (Mandado de Segurança n. 34.070), o raciocínio foi em direção oposta, pois não foi visto como afronta à dignidade da Suprema Corte a alegação dos autores da ação de que haveria impunidade caso houvesse deslocamento da competência para 
o Supremo Tribunal Federal, pelo foro por prerrogativa de função de Ministro de Estado, sendo deferido o pedido de liminar e impedida a posse. Também foi em sentido oposta a decisão ao adentrar no mérito administrativo do ato da Presidente da República, não reconhecendo que teria a Presidente agido dentro de suas atribuições.

Assim, ainda que narradas de forma bastante breve as situações fáticas e jurídicas que ensejaram as ações, pôde-se perceber que são situações que guardam relação de similaridade entre si, mas que tiveram tratamento diametralmente opostos.

\subsection{Ações Cautelares n. 4.039 (Caso Delcídio) e n. 4.327 (Caso Aécio)}

No presente tópico serão abordadas as decisões da Ação Cautelar n. 4.039, que tratou de pedido de medidas restritivas de liberdade contra o Senador da República Delcídio do Amaral Gomez, e da Ação Cautelar n. 4.327, acerca das pretendidas medidas restritivas de liberdade contra o Senador da República Aécio Neves da Cunha.

Tais casos concretos têm grande proximidade fático-jurídica entre si, mas com decisões com grande distância entre si.

A primeira, de número 4.039, autuada em 24/11/2015, para relatoria do saudoso Ministro Teori Zavascki, em que é requerente o Ministério Público Federal, e requeridos o Senador Delcídio do Amaral Gomez, André Santos Esteves, Edson Siqueira Ribeiro Filho e Diogo Ferreira Rodrigues, sendo que para o presente trabalho será considerada a decisão no que tange às medidas restritivas de liberdade em desfavor do Senador da República.

O pedido do Ministério Público Federal lastreava-se em conversas telefônicas interceptadas, nas quais se verificou a possibilidade de haver futura obstrução da Justiça por parte 
dos requeridos, que ofereceram a Nestor Cerveró a possibilidade de fuga da prisão e do Brasil, na tentativa de dissuadi-lo de colaborar com o Ministério Público nas investigações atinentes à Operação Lava Jato.

O Ministro Relator, tendo como fundamento principal a garantia da instrução criminal e a necessidade de se resguardar a Ordem Pública, entendeu que estavam presentes os requisitos do art. 312 do Código de Processo Penal e, assim, decretou a prisão cautelar do Senador Delcídio Amaral, após a qual os autos do processo deveriam ser encaminhados para o Senado Federal, para apreciação da prisão, conforme referido art. 53, $\S 2^{\circ}$, da CF. Ou seja, a autorização prévia se tornou autorização a posteriori no presente caso analisado.

Na segunda ação em análise, de número 4.327, autuada em 15/05/2017, para relatoria do Ministro Marco Aurélio, é requerente o Ministério Público Federal, e requerido o então Senador Aécio Neves.

A prisão do Senador foi requerida pelo Procurador-Geral da República, que entendeu ser imprescindível, pelos seguintes fundamentos:

(i) existência de indícios da prática dos crimes de corrupção passiva, lavagem de capitais, pertinência à organização criminosa e obstrução à investigação de organização criminosa; (ii) permanência de estado de flagrância do Senador Aécio Neves da Cunha quanto aos delitos de organização criminosa, considerando a natureza permanente do delito; (iii) possibilidade de prisão preventiva, à compreensão de que o artigo $53, \S 2^{\circ}$, da $\mathrm{CF}$, impõe ser reinterpretado, em ordem a autorizar prisões cautelares de congressistas fora das hipóteses de flagrante; (iv) existência de precedentes da Corte no sentido de autorizar a prisão de congressista (AC 4039, caso Delcídio Amaral); (v) descumprimento das medidas cautelares alternativas à prisão fixadas pelo eminente Ministro Edson Fachin, na medida em que o Senador Aécio Neves da Cunha “(...) 
apesar da suspensão do exercício das funções parlamentares (...) continuou empreendendo ações de articulação política relacionadas à pauta do Congresso Nacional”. (STF, 2017, grifos no original).

Destaca-se que o Procurador-Geral da República enfatiza a situação de flagrância em decorrência da prática do crime de organização criminosa, que é crime permanente, e utiliza como precedente justamente a outra ação aqui analisada (n. 4039), na qual houve determinação pelo Supremo Tribunal Federal da prisão de Senador da República por prática do mesmo delito criminoso.

Diferentemente do caso paradigma, aqui prevaleceu o posicionamento de que não poderia o STF, por meio de decisão monocrática, determinar a prisão de congressistas.

Com especial apreço à interpretação da Constituição, que deve ser feita se levando em consideração sua unidade textual, decidiu-se que não se poderia superar a literalidade do artigo 53, $\S 2^{\circ}$ da Constituição Federal, sob pena de se incorrer em risco de violação à separação de Poderes, que consistiria em violação da própria Constituição.

Em ambos os casos houve prova inequívoca de prática de vários crimes, dentre os quais o de Organização Criminosa. No entanto, em um, foi determinada, por decisão monocrática, a prisão de Senador da República a despeito do art. 53, $\S 2^{\circ}$, da Constituição Federal, e, em outro, o entendimento foi o oposto, no sentido de que tal decisão não poderia ser em cognição monocrática, e que não poderia haver supressão do poder do Senado Federal de autorizar a prisão.

Assim, ainda que narradas de forma bastante breve as situações fáticas e jurídicas que ensejaram as ações contra os senadores da República, Delcídio Amaral (AC 4039) e Aécio Neves (AC 4327), pôde-se perceber que são situações que 
guardam relação de similaridade entre si, mas que tiveram tratamento diametralmente opostos.

\section{ANÁLISE QUANTO A TER OU NÃO HAVIDO CARÁTER ATIVISTA E/OU AUTORRESTRITIVO NAS DECISÕES ESTUDADAS}

Nos casos estudados, olhando pela perspectiva atual do constitucionalismo, com relevância indiscutível do Poder Judiciário, com " [...] a incumbência de exercer o controle político-jurídico da atividade dos demais Poderes de forma definitiva [...]" (LEITE, 2016, p. 27), pode-se entender que mesmo na decisão que adentrou no mérito administrativo (MS 34070 caso Lula), e na que interpretou a Constituição de forma relativizada (AC 4039 - caso Delcídio Amaral), agiu de acordo com seu papel de maior ascensão, que, "para alguns [...] nas democracias modernas é a consolidação e consequente evolução da mencionada teoria dos freios e contrapesos aliada à ideia de supremacia da Constituição [...]" (LEITE, 2016, p. 27).

De outro norte, nas outras duas decisões analisadas, o Poder Judiciário agiu de forma deferente aos demais Poderes, ao respeitar ato administrativo de nomeação de Ministro de Estado pelo Presidente da República (MS 34069 - caso Moreira Franco).

Da mesma maneira agiu ao determinar, em respeito à separação de Poderes, que a interpretação da Constituição não pode se relativizada, no que tange ao art. $53, \S 2^{\circ}$, que atribui ao Poder Legislativo o poder de decidir quanto à possibilidade, ou não, de prisão de membro do Senado ou da Câmara Federal, salvo em caso de flagrante delito de crime inafiançável, e que, mesmo nesse caso a decisão não pode ser monocrática (AC 4327 - caso Aécio Neves). 
Nesses casos pode-se dizer que houve atitude de autorrestrição ou autocontenção do Judiciário, que é " [...] uma atitude política do juiz constitucional, pois na maioria das vezes caberá a ele decidir que não lhe cabe decidir determinada questão" (FONTES, 2018, p. 218, grifos no original).

Sendo assim, pode-se concluir que no que se chamou de "caso Lula" e "caso Delcídio Amaral", houve atuação ativista por parte do Supremo Tribunal Federal, pois, (i) no primeiro, o Poder Judiciário se substituiu ao Poder Executivo, ao interpretar a subjetividade da intenção do Ato Administrativo da Presidente da República, determinando o Ministro Relator que houve, por parte do Chefe do Executivo, atuação intencional de fraudar a Constituição, com desvio de finalidade; e (ii) no segundo, o Poder Judiciário interpretou o texto constitucional de modo a modificar o seu sentido, para possibilitar a atribuição de sentido que se adequasse à decisão, e, com isso, no mínimo, mitigou poderes legítimos do Legislativo, a quem incumbe deliberar previamente se cabe ou não prisão de seus representantes eleitos, e não ser essa deliberação feita posteriormente à prisão, o que foi possível pelo fato de ter o Ministro Relator, em decisão monocrática, liminarmente, interpretado que houve flagrante de crime inafiançável de Organização Criminosa, por ser crime permanente.

Assim, os respectivos Relatores dos casos, ao interpretarem a Constituição, para a obtenção de uma finalidade, agiram de forma proativa em detrimento da separação dos Poderes, (ALVES; LEAL, 2015, p. 189), e isso se dá porque "o ativismo praticado no Brasil vem marcado pela absoluta falta de racionalidade na produção das decisões judiciais, que não seguem qualquer padrão, metodologia ou critério capaz de conferir a mínima coerência e integridade do ordenamento jurídico" (TRINDADE; OLIVEIRA, 2017, p. 236-237), corroborando a ideia de que "ativismos judiciais e discricionariedades interpre- 
tativas caminham, no mais das vezes, lado a lado" (STRECK, 2017, p. 462).

\subsection{Decisões juridicamente antagônicas a casos semelhantes - possibilidade de insegurança jurídica delas decorrente}

Diante de situações idênticas, levadas a juízo sob mesmos fundamentos jurídicos, deveria ser dada a mesma solução jurídica, com respeito ao princípio ubieadem legis ratio, ibieademdispositio, que pode ser traduzido por "onde há a mesma razão legal, aplica-se o mesmo dispositivo" (ESTEFAM, 2019, p. 79), bem como em respeito ao "[...] princípio da igualdade [que] impõe a construção de mecanismos de padronização decisória, vez que é essencial assegurar que, diante de casos idênticos, as soluções alcançadas por meio da atividade processual sejam idênticas" (CÂMARA, 2018, p. 350).

Nas quatro decisões analisadas, relatadas cada qual por um Ministro, com respostas jurídicas diversas para situações similares, percebe-se que não há um posicionamento da Corte, mas posicionamentos individuais dos Ministros. (BOGOSSIAN; SANTOS DE LAMEIDA, 2017, p. 116-117).

Há que se ter parâmetros, limitações cognitivas para que se possa ao menos buscar alcançar um padrão decisório que diminua a influência do subjetivismo, pois, do contrário, se o subjetivismo não encontrar limites, poderá ir além de interpretação jurídica e se tornar discricionariedade, ainda que existam os "casos difíceis" em que "[...] não existe uma solução pré-pronta no Direito [e] a solução terá de ser construída argumentativamente, à luz dos elementos do caso concreto, dos parâmetros fixados na norma e de elementos externos ao Direito" (BARROSO, 2016, p. 347).

Julgamento que tem como objeto as consequências esbarra 
no subjetivismo do julgador, e pode ser um passo em direção a discricionariedades e arbitrariedades, pois “[...] como os juízes, a exemplo de qualquer pessoa, discordam sobre o valor relativo das diferentes consequências possíveis de suas decisões, dizerlhes que decidam por avaliação das consequências não passa de [...] um convite à ilegalidade" (DWORKIN, 2016, p. 146).

Nos casos analisados, mesmo tendo uma decisão recente de caso semelhante em um sentido, foi decidido o caso posterior de maneira bastante distinta, contrariando a lógica da importância de se respeitar procedentes, pois "uma aplicação integrativa e coerente do Direito deve, necessariamente, levar em cota o modo pelo qual determinado tribunal ou como os outros tribunais do país vêm decidindo determinada matéria" (STRECK, 2017, p. 399).

Disso decorre que "a coerência assegura a igualdade, isto é, que os diversos casos terão a igual consideração por parte dos juízes [e] a integridade significa rechaçar a tentação da arbitrariedade, que, no mais das vezes, é variante da discricionariedade" (STRECK, 2017, p. 399-400 - grifos no original).

Para que se possa ter num mesmo órgão uma mudança de posicionamento, ainda que diverso o relator, como visto, deve haver um ônus argumentativo, eis que "não se pode decidir casuisticamente sem que se faça um esforço hermenêutico para justificar por que o caso que ora se decide merece um tratamento diferente com relação aos outros que já foram decididos" (STRECK, 2017, p. 587).

Esse encargo hermenêutico e argumentativo deve ser mantido mesmo que seja para alterar posicionamento de decisão não vinculativa, pois

os padrões decisórios argumentativos ou persuasivos, não obstante desprovidos de eficácia vinculativa, nem por isso podem ser ignorados (o que resulta dos deveres de uni- 
formidade, coerência e integridade previstos no art. 926 do CPC/2015), sendo responsáveis pela existência de um "ônus argumentativo (retius, um dever de argumentação) para o órgão julgador que deles se afaste (CÂMARA, 2018, p. 355).

Dessa forma, "[...] aquele que possuir o melhor argumento, do ponto de vista abstrato, pode quebrar o elo da cadeia histórica e firmar um novo sentido para a decisão que se coloca em tela" (STRECK, 2017, p. 587), o que nos leva ao tema da segurança jurídica.

A segurança, na Constituição de 1988, vem prevista como um dos valores supremos que fundam a instituição do Estado Democrático Direito, pois “'[...] constitui, por si só, uma referência de segurança", que pode ser traduzida como "[...] a qualidade daquilo que está livre de perigo, livre de risco, protegido, acautelado, garantido, do que se pode ter certeza ou, ainda, daquilo em que se pode ter confiança, convicção" (PAULSEN, 2019, p. 81).

Uma forma de se alcançar essa segurança jurídica é por meio do respeito aos precedentes, o que contribui para "[...] o enriquecimento da previsão de regras jurídicas", que é meio para se buscar a estabilidade das decisões, no sentido de haver estabilidade "[...] das regras estabelecidas pelo Judiciário." (MOTTA, 2012, p. 45-47).

Havendo previsibilidade das decisões, haveria também maior segurança jurídica e, e o que fortalece a estabilidade democrática.

Preservar o Estado Democrático de Direito é não permitir que

[...] depois da superação dos autoritarismos / totalitarismos surgidos no século XX e no momento em que alcançamos esse (elevado) patamar de discussão democrática do Direito, viéssemos a "depender" da discricionariedade dos 
juízes na discussão dos assim denominados "casos difíceis" ou em face das (inexoráveis) incertezas da linguagem (STRECK, 2017, p. 522).

As decisões analisadas despertam o alerta para essa questão, pois foram fatos similares, subsidiados pelas mesmas regras jurídicas, mas que tiveram soluções jurisdicionais opostas, eivadas de subjetivismo e relativismo, sob a capa da interpretação, da pré-compreensão da norma pelo julgador.

Não se pode olvidar que a discricionariedade, por sua vez, vista de outro ponto de vista, pode ter o papel de exercer "[...] uma função importante no direito, principalmente no direito constitucional, pois auxilia a compreender como autoridades e tribunais estão vinculados pela constituição enquanto, ao mesmo tempo, atribuem uma margem de flexibilidade de acordo com as características do caso em questão" (KLATT; SHMIDT, 2016, p. 185).

Há que se dizer, porém, que não se pode afastar do dever de preservar o Estado Democrático de Direito, princípio fundamental insculpido no artigo $1^{\circ}$ da Constituição Federal, e do qual decorre também o dever de que haja segurança jurídica, que pode ser obtida por meio de padrões decisórios e previsibilidade da resposta jurisdicional, mormente em casos semelhantes.

Tal subjetivismo decisionista deve ser evitado, pois " [...] a dependência de convicções pessoais do julgador enfraquece a democracia, em especial na questão da responsabilidade do juiz" (TRINDADE; OLIVEIRA, 2017, p.237), e isso decorre do fato de que "apenas em um sistema que predomina a vontade do mais forte é que se poderia medir a justiça pela vontade de alguém, por mais absurda que ela fosse [e] no Estado Democrático de Direito, a justiça não se mede pela vontade de ninguém, nem pela do STF". (ABBOUD; NERY JÚNIOR apud TRINDADE; OLIVEIRA, 2017, p. 237). 
Existe uma situação generalizada de imprevisibilidade das decisões decorrentes, reiterada e majoritariamente, de voluntarismo decisório, que ocorre "[...] nas decisões ad hoc, na qual há um casuísmo tamanho que não é possível lhe impor regras gerais a partir de semelhanças ou dessemelhanças com outros casos", sendo preciso, para evitar a incerteza e insegurança jurídica, que "[...] suas razões de decidir (ratiodecidendi) possibilitem que a decisão seja inserida em uma cultura de precedentes." (TRINDADE; OLIVEIRA, 2017, p. 238).

A razão de decidir, ratiodecidendi, diferencia-se daobiterdicta, pois "a ratiodecidendi refere-se às premissas necessárias à decisão. Já os argumentos ditos de passagem, que não se revelam vitais para a manutenção do julgado, são denominados obiterdicta" (PUGLIESE, 2016, p. 79).

É dizer, em outras palavras, que a ratiodecidendi é “[...] a regra jurisprudencial fundamental, o cerne da decisão" e, quanto aos fundamentos argumentativos da obiterdicta, "[...] embora não tenham caráter imperativo, permitem compreender a decisão graças às opiniões dadas pelos juízes 'incidentalmente', na forma de digressões (bytheway)" (SÉROUSSI apud PUGLIESE, 2016, p. 80).

A teoria unitária do ordenamento jurídico, adotada pelo Brasil, está umbilicalmente ligada à almejada segurança jurídica, sendo que "[...] o processo não constitui um fim em si mesmo, mas está relacionado a uma função social que prevê a necessidade de uniformização dos julgamentos [...]" (LOVATO, 2018, p. 20).

Outro elemento que é prejudicial à segurança jurídica é a discricionariedade, que se dá por meio do livre convencimento, pois "não apenas a insegurança jurídica é consequência, como também a violação à unicidade da jurisdição, [compe- 
tindo] à magistratura promover essa unicidade, e causas já julgadas devem ser respeitadas como precedentes" (LOVATO, 2018, p. 20-21).

A previsibilidade das decisões jurídicas, por meio da segurança jurídica é de suma importância para o Direito, pois sendo garantidor da Democracia, deve-se, “[...] de um lado, preservar a força normativa da Constituição e, de outro, não colocar a política a reboque do Direito [bem como não] deixar que a moral corrija o Direito" (STRECK, 2017, p. 629-630).

Há que se compreender, portanto, diante de todo o exposto, quanto às decisões analisadas, antagônicas entre si, mesmo sendo similares os casos julgados, contribuíram para a insegurança jurídica, o que pode acarretar prejuízos ao Estado Democrático de Direito e, via de consequência, à Democracia brasileira.

\section{CONCLUSÃO}

No presente trabalho não se pretendeu atribuir valoração às decisões, no sentido de julgá-las corretas ou não, mas tão somente analisar, de forma objetiva e diante dos preceitos jurídicos pertinentes, os posicionamentos decisórios diferentes do Supremo Tribunal Federal em situações fáticas e jurídicas similares entre si.

A Constituição Federal de 1988, extensa e analítica, a evolução dos direitos fundamentais e a importância da dignidade da pessoa humana acarretam a constitucionalização do Direito, em seus vários ramos, impactando a Política e influenciando a atuação dos Poderes da República, que devem agir pautados pela Constituição.

Sendo o Supremo Tribunal Federal, por força do texto 
constitucional, o guardião da Constituição, suas decisões repercutem em toda a sociedade brasileira.

Ainda assim, é preservada a separação de poderes, porque o Judiciário atua dentro de sua função judicante, ainda que por vezes em seu papel contramajoritário, mas legitimado democraticamente pela própria Constituição, que atribui as funções e limites dessa atuação.

O ativismo judicial pode ocorrer não apenas para concretizar direitos fundamentais, de maneira a criar normas, imiscuindo-se, o Judiciário, na função legislativa, mas em sua função legítima, de interpretar o texto constitucional e as demais normas do ordenamento jurídico.

Em outras vezes, o Judiciário atua de maneira a se autorrestringir, preservando as relações institucionais e evitando desgastes e crises entre os Poderes da República.

Nas decisões analisadas foi possível perceber a atuação ativista do Supremo Tribunal Federal, que, em sua função jurisdicional, expandiu a possibilidade interpretativa das normas, possibilitando tanto o controle do ato administrativo, como ocorreu no denominado Caso Lula, em que se adentrou no mérito administrativo, suspendendo eficácia de nomeação de Ministro de Estado pelo Presidente da República, sob o argumento de que teria havido desvio de finalidade e, portanto seria ilegal e nulo o ato.

Também ocorreu ativismo judicial no denominado Caso Delcídio, no qual houve interpretação do texto de modo atribuir sentido mais amplo aos conceitos de flagrante delito e quanto ao momento em que deveria haver deliberação pelo Senado acerca da possibilidade de prisão de Senador da República.

Do mesmo modo, por meio de decisões do Supremo Tri- 
bunal Federal, também em sua função interpretativa e jurisdicional, foi possível perceber a atuação autorrestritiva, ao não adentrar no mérito administrativo de nomeação de Ministro de Estado por Presidente da República, no denominado Caso Moreira Franco, e também no denominado Caso Aécio, em que interpretou e decidiu de maneira a preservar maior separação de poderes, mantendo a decisão sobre a possibilidade de prisão de Senador da República para o próprio Senado Federal.

Comparando-se as situações fáticas e jurídicas, percebe-se que, mesmo sendo quase idênticas, as decisões foram bastante diferentes, com interpretações divergentes entre si, sendo possível verificar o risco que acarreta à segurança jurídica, imprescindível ao Estado Democrático de Direito.

A segurança jurídica é de extrema importância, pois ao se possibilitar a previsibilidade das decisões, gera-se estabilidade nas relações jurídicas, evitando-se surpresas que possam minar a confiança no Judiciário e gerar crises institucionais, o que é pernicioso a todos os Poderes da República.

Dessa forma, pode-se concluir que a atuação do Supremo Tribunal Federal deve levar em conta as decisões precedentes, para que se tenha previsibilidade das decisões, garantindo maior segurança jurídica e estabilidade à Democracia, solidificando cada vez mais os pilares do Estado Democrático de Direito.

\section{REFERÊNCIAS}

ALVES, Felipe Delenogare; LEAL, Mônia Clarissa Henning. Judicialização e ativismo judicial: o Supremo Tribunal Federal entre a interpretação e a intervenção na esfera de atuação dos demais poderes. Rio de Janeiro: Lumen Juris, 2015.

BARROSO, Luís Roberto. Curso de direito constitucional contemporâneo. 5. ed. São Paulo: Saraiva, 2016.

BOGOSSIAN, Andre; ALMEIDA, Danilo dos Santos de. É possível falar em precedente "do supremo"?.In: FALCÃO, Joaquim; ARGUELHES, Diego W; RECONDO, Felipe. Onze supremos: o supremo em 2016. Belo Horizonte: Letramento: Casa do 
Direito: Supra: Jota: FGV Rio, 2017.

BONAVIDES, Paulo. Curso de direito constitucional. 19. ed. atual. São Paulo: Malheiros, 2006.

BRASIL. Constituição da República Federativa do Brasil (1988). Disponível em: http://www.planalto.gov.br/ccivil_03/constituicao/constituicaocompilado.htm. Acesso em: 15 fev. 2019.

BRASIL. Supremo Tribunal Federal. Ação Cautelar n. 4.039, do Distrito Federal. Autor: Ministério Público Federal. Réu: Delcídio do Amaral Gómez. Relator: Min. TeoriZavaski. Disponível em: www.stf.jus.br: http://portal.stf.jus.br/processos/detalhe. asp?incidente=4892330. Acesso em: 12 mar. 2019.

BRASIL. Supremo Tribunal Federal. Ação Cautelar n. 4.327, do Distrito Federal. Autor: Ministério Público Federal. Réu: Aécio Neves da Cunha. Relator: Min. Marco Aurélio. Disponível em: www.stf.jus.br: http://portal.stf.jus.br/processos/detalhe.asp?incidente=5188006. Acesso em: 12 mar. 2019.

BRASIL. Supremo Tribunal Federal. Medida Cautelar em Mandado de Segurança n. 34.070 Distrito Federal. Impetrante: Partido Popular Socialista - PPS. Impetrado: Presidente da República. Relator: Min. Gilmar Mendes. Disponível em: www.stf.jus. br: https://www.stf.jus.br/arquivo/cms/noticiaNoticiaStf/anexo/ms34070.pdf. Acesso em: 10 mar. 2019.

BRASIL. Supremo Tribunal Federal. Medida Cautelar em Mandado de Segurança n. 34.609, do Distrito Federal. Impetrante: Rede Sustentabilidade. Impetrado: Presidente da República. Relator: Min. Celso de Mello. Disponível em: www.stf.jus.br: http://portal.stf.jus.br/processos/downloadPeca.asp?id=311226749\&ext=.pdf. Acesso em: 10 mar. 2019.

BULOS, UadiLammêgo. Curso de direito constitucional. 11. ed. rev. e atual. São Paulo: Saraiva. 2018.

CÂMARA, Alexandre Freitas. Levando os padrões decisórios a sério. São Paulo: Atlas, 2018.

CAMPOS, Carlos Alexandre de Azevedo. Dimensões da autorrestrição judicial.In: LEITE, George Salomão; STRECK, Lenio Luiz.; NERY JR, Nelson. Crise dos poderes da república: judiciário, legislativo e executivo. São Paulo: Revista dos Tribunais, 2017.

CAPPELLETTI, Mauro. Juízes legisladores? Porto Alegre: Sérgio Antônio Fabris Editor, 1993 / Reimpressão, 1999.

DWORKIN, Ronald. A justiça de toga. São Paulo: Editora WMF Martins Fontes, 2010.

ESTEFAM, André. Direito penal, volume 1: parte geral (arts. $1^{\circ}$ a 120). 8. ed. São Paulo: Saraiva Educação, 2019.

FALCÃO, Joaquim; ARGUELHES, Diego W; RECONDO, Felipe. Onze supremos: o supremo em 2016. Belo Horizonte: Letramento: Casa do Direito: Supra: Jota: FGV Rio, 2017.

FILETI, Narbal Antônio Mendonça. A fundamentalidade dos direitos sociais e o 
princípio da proibição de retrocesso social. Florianópolis: Conceito Editorial, 2009.

FONTES, Paulo Gustavo Guedes. Neoconstitucionalismo e verdade: limites democráticos da jurisdição constitucional. Rio de Janeiro: Lumen Juris, 2018.

FONTES, Paulo Gustavo Guedes. Neoconstitucionalismo e verdade: limites democráticos da jurisdição constitucional. Rio de Janeiro: Lumen Juris, 2018.

KLATT, Matthias;SCHMIDT, Johannes. In: MORAIS, Fausto Santos de; BORTOLOTI, José Carlos Kraemer. A jurisdição constitucional e os desafios à concretização dos direitos fundamentais. Rio de Janeiro: Lumen Juris, 2016.

LEITE, Carlos Henrique Costa. Supremacia judicial e justiça de transição: a última palavra sobre o significado da constituição e o caso da lei da anistia. Rio de Janeiro: Lumen Juris, 2016.

LEITE, George Salomão; STRECK, Lenio Luiz; NERY JR, Nelson. Crise dos poderes da república: judiciário, legislativo e executivo. São Paulo: Editora Revista dos Tribunais, 2017.

LOVATO, Luiz Gustavo. Direito processual civil: o novo modelo processual brasileiro, common law e a teoria unitária do ordenamento jurídico. 2. ed. Florianópolis: EModara, 2018.

MIRANDA, Jorge. Teoria do estado e da constituição. 4. ed. Rio de Janeiro: Forense, 2015.

MORAES, Filomeno. Executivo e legislativo no brasil pós-constituinte. São Paulo Perspec. São Paulo,v. 15, n. 4, p. 45-52, Dec. 2001. Disponível em: http://www.scielo. br/scielo.php?script=sci_arttext\&pid=S010288392001000400006\&lng=en\&nrm=iso. Acesso em: 15 fev. 2019.

MOTTA, Francisco José Borges. Levando o direito a sério: uma crítica hermenêutica ao protagonismo judicial. 2.ed. rev. e ampl. Porto Alegre: Livraria do Advogado, 2012.

PASSOS, Daniel Silva. Intervenção judicial nas políticas públicas: o problema da legitimidade. São Paulo: Saraiva, 2014.

PAULSEN, Leandro. Curso de direito tributário completo. 10. ed. São Paulo: Saraiva Educação, 2019.

POGREBINSCHI, Thamy. Judicialização ou representação? Política, direito e democracia no Brasil. Rio de Janeiro: Elsevier, 2011.

PUGLIESE, William. Precedentes e a civil lawbrasileira: interpretação e aplicação do novo Código de Processo Civil. São Paulo: Editora Revista dos Tribunais, 2016.

SARMENTO, Daniel; SOUZA NETO, Cláudio Pereira de. Direito constitucional: teoria, história e métodos de trabalho. 2. ed. 3. reimpr. Belo Horizonte: Fórum, 2017

SILVA, José Afonso da. Curso de direito constitucional positivo. 32. ed. rev. e atual. São Paulo: Malheiros Editores. 2008.

STRECK, Lenio Luiz. Mut(il)ação constitucional: de como os ativismos obscurecem o debate acerca dos limites da jurisdição.In: LEITE, George Salomão; STRECK, Lenio Luiz.; NERY JR, Nelson. Crise dos poderes da República: judiciário, legislativo e executivo. São Paulo: Editora Revista dos Tribunais, 2017. 
STRECK, Lenio Luiz. Verdade e consenso. 6. ed. rev. e ampl. São Paulo: Saraiva, 2017.

TRINDADE, André Karam; OLIVEIRA, Rafael Tomaz. Os impactos do ativismo judicial no sistema político: notas sobre a relação entre o judiciário e os demais poderes em tempos de crise política. In: LEITE, George Salomão.; STRECK, Lenio Luiz.; NERY JR, Nelson. Crise dos poderes da república: judiciário, legislativo e executivo. São Paulo: Editora Revista dos Tribunais, 2017.

Recebido em: 24/04/2019

Aprovado em: 31/05/2019 